\title{
Gene expression signature: a powerful approach for drug discovery in diabetes
}

\author{
Smithamol Sithara', Tamsyn M Crowley², Ken Walder ${ }^{1}$ and Kathryn Aston-Mourney \\ ${ }^{1}$ Metabolic Research Unit, School of Medicine, Deakin University, Geelong, Australia \\ ${ }^{2} S$ chool of Medicine, MMR, Bioinformatics Core Research Facility, Deakin University, Geelong, Australia
}

Correspondence should be addressed to K Aston-Mourney Email

k.astonmourney@deakin. edu.au

\begin{abstract}
Type 2 diabetes (T2D) is increasing in prevalence at an alarming rate around the world. Much effort has gone into the discovery and design of antidiabetic drugs; however, those already available are unable to combat the underlying causes of the disease and instead only moderate the symptoms. The reason for this is that T2D is a complex disease, and attempts to target one biological pathway are insufficient to combat the full extent of the disease. Additionally, the underlying pathophysiology of this disease is yet to be fully elucidated making it difficult to design drugs that target the mechanisms involved. Therefore, the approach of designing new drugs aimed at a specific molecular target is not optimal and a more expansive, unbiased approach is required. In this review, we will look at the current state of diabetes treatments and how these target the disease symptoms but are unable to combat the underlying causes. We will also review how the technique of gene expression signatures (GESs) has been used successfully for other complex diseases and how this may be applied as a powerful tool for the discovery of new drugs for T2D.
\end{abstract}
Key Words
- gene expression signature
- type 2 diabetes
- drug discovery
- complex disease

\section{Introduction}

Type 2 diabetes (T2D) is an increasing problem currently affecting the health and lifestyle of more than 422 million people worldwide (NCD-RisC 2016), a number that is expected to rise to 592 million by 2035 (Guariguata et al. 2014). T2D is characterised by two main defects, insulin resistance and beta-cell dysfunction that together contribute to the diabetic milieu.

Under normal conditions, when there is a rise in blood glucose, glucose is transported into the pancreatic beta-cell via glucose transporters where it undergoes glycolysis and signals for insulin to be secreted (Ashcroft \& Rorsman 2012, Esguerra et al. 2014). However, under insulin-resistant conditions, typically associated with obesity, the increased levels of plasma glucose stimulate the beta-cells to produce more insulin by increasing both their secretory activity and mass (Butler et al. 2003, Weir $\&$ Bonner-Weir 2004). Therefore, even in the presence of insulin resistance, normoglycaemia can be maintained (Steil et al. 2001, Jetton et al. 2005, Nolan et al. 2006). However, when the beta-cell is also predisposed to failure, due to complex genetic and environmental factors, this continuous demand to increase the amount of insulin production can result in beta-cell failure, where beta-cell function and mass deteriorate resulting in hyperglycaemia (Leahy 2005). Importantly, the conversion of beta-cell adaptation to beta-cell deterioration can be a slow process 
as evidenced by the slow progression (usually over several years) of subjects with impaired glucose tolerance (IGT), a pre-diabetic state, to overt diabetes (Motala et al. 1993, Tuomilehto et al. 2001).

Multiple genetic and environmental factors are associated with T2D and are thought to contribute to the imbalance in tightly regulated metabolic processes, and this eventually leads to the complexity surrounding the pathogenesis of T2D. The genetic component is evident in family and population based studies in patients who are at risk of T2D (Lehtovirta et al. 2000, Grarup et al. 2007, Voight et al. 2010). Additionally, a number of large genome-wide association studies have identified risk loci that could be involved in the pathogenesis of T2D (Sandhu et al. 2007, Scott et al. 2007, Sladek et al. 2007, Zeggini et al. 2008, Saxena et al. 2012, DIAGRAM et al. 2014). However, although more than 80 loci have been identified, each of this is a common variant that only has a small effect to increase the risk of T2D (Andersen et al. 2016). Further, with most of these loci, the causal variant has not been identified (Andersen et al. 2016). Therefore, although we are slowly increasing our understanding of the genetic basis of T2D, we are still a long way away from having a complete view. In addition to the genetic factors, many environmental factors play important roles in the development of T2D. These factors include increased caloric and the nutrient composition of food intake, reduced energy expenditure, the in utero environment, gut microbiome, alterations in diurnal patterns and exposure to different chemicals (reviewed in Kahn et al. 2014). Not only are the genetic and environmental factors involved in this disease complex but also the cellular mechanisms are just as complex. Glucotoxicity, lipotoxicity, oxidative stress, endoplasmic reticulum stress, islet amyloidogenesis, inflammation, altered neuronal signalling and epigenetic reprogramming have all been shown to play a role in the pathophysiology of T2D (reviewed in Hull et al. 2004, McGee \& Hargreaves 2010, Bensellam et al. 2012, Biden et al. 2014, Kahn et al. 2014). Therefore, it is clear that the causative and contributory genetic and environmental factors involved in T2D as well as the cellular mechanisms mediating their effects are all very complex, and we are still a long way from fully understanding this multifactorial interplay.

Given the complex nature of T2D, it stands to reason that any effective treatment will have to target multiple aspects of the underlying mechanisms causing the disease, which will be very difficult. One of the best ways to combat T2D is lifestyle interventions aimed at prevention. Lifestyle interventions including diet and increased exercise resulting in weight loss can successfully reduce the development of T2D in high-risk populations (Tuomilehto et al. 2001, Knowler et al. 2002). Further, lifestyle interventions after the development of T2D are also recommended as continual treatment strategies to improve glycaemic control and reduce complications (American Diabetes Association 2016, Royal Australian College of General Practitioners 2016). However, lifestyle changes alone cannot combat the epidemic of diabetes and despite these recommendations, and available therapies, not enough patients with type 2 diabetes mellitus achieve adequate glycaemic control (Mitka 2013). Below, we review the antidiabetic medications currently available and their possible limitations, highlighting the need for an unbiased drug discovery tool that can overcome the complex nature of T2D.

\section{Current therapeutic approaches for T2D}

The increasing prevalence of $\mathrm{T} 2 \mathrm{D}$ has led to different approaches in the discovery of new therapeutic targets for the treatment of hyperglycaemia. Currently, there are numerous oral and injectable drugs available for the treatment of T2D. Although the main focus of these current treatments is to achieve glycaemic control and to delay the complications associated with the disease, achieving and maintaining long-term glycaemic control is challenging (Aston-Mourney et al. 2008). In addition, although they act to lower blood glucose, which is beneficial, they generally do not directly contribute to improving the underlying causes of T2D.

There are many classes of antidiabetic drugs available for the treatment of T2D including biguanides, thiazolidinediones, sulphonylureas, glucagon-like peptide-1 (GLP-1) modulators (GLP-1 mimetics and gliptins), $\alpha$-glucosidase inhibitors, sodium-linked glucose transporter 2 (SGLT2) inhibitors and exogenous insulin, which are each described in Table 1 . These drugs are given alone or in combination depending on the level of glycaemic control obtained by each individual.

\section{The need for new T2D therapies}

There is an ongoing search for the development of therapeutic agents with new mechanisms of action and

Published by Bioscientifica Ltd 
Table 1 Current antidiabetic drugs classes, action and limitations.

\begin{tabular}{|c|c|}
\hline Drug class & Mode of action \\
\hline Biguanides & $\begin{array}{l}\text { Reduce hepatic gluconeogenesis (Inzucchi et al. } \\
\text { 1998, Zhou et al. 2001), oxidation of fatty } \\
\text { acids (Geerling et al. 2014) and glycogenolysis } \\
\text { (Chu et al. 2000) }\end{array}$ \\
\hline Thiazolidinediones & $\begin{array}{l}\text { - Increase glucose disposal via activating PPAR- } \gamma \\
\text { to improve insulin signalling in liver, adipose } \\
\text { tissue and skeletal muscles (Maggs et al. 1998, } \\
\text { Miyazaki et al. 2001, 2003, Kim et al. 2002) }\end{array}$ \\
\hline Sulphonylureas & $\begin{array}{l}\text { - Directly increase insulin secretion via closing } \\
\text { potassium-ATP channel (SUR-1 subunit) on beta- } \\
\text { cells (Proks et al. 2002) }\end{array}$ \\
\hline
\end{tabular}

GLP-1 analogues and Gliptins (dipeptidyl peptidase-4 (DPP-4) inhibitors)

Alpha glucosidase inhibitors (AGI)

SGLT 2 inhibitors

Insulin

- Directly reduces glycaemia by increasing glucose uptake and inhibiting hepatic glucose production (Luzi et al. 1988)

\section{Limitations}

- Little effect on disease progression

- Antidiabetic effect declines over time (Weeks \& Lathrop 1995)

- Gastrointestinal side effects (Florez et al. 2010)

- Rare lactic acidosis side effects (Misbin 2004)

- Risk of weight gain, congestive heart failure and fractures (Gegick \& Altheimer 2004)

- Only effective during initial stages of the disease when functional beta-cells are present (Hemmingsen et al. 2014)

- Fail to provide adequate glycaemic control over the long term (Fu et al. 2012)

- Side effects such as nausea, vomiting and diarrhoea (Dungan et al. 2014, Fineman et al. 2004)

- Cases of pancreatitis reported in both animal (Nachnani et al. 2010, Gier et al. 2012) and human studies (Ayoub et al. 2010, Elashoff et al. 2011, Lai et al. 2015) with prolonged use

- Must be delivered by injection

- Long-term effects currently unknown

- Frequent side effects such as flatulence, diarrhoea, abdominal pain, nausea and vomiting (Dabhi et al. 2013)

- Increased incidence of genital and urinary tract infections (Chao \& Henry 2010, Berhan \& Barker 2013)

- Increased risk of diabetic ketoacidosis (Erondu et al. 2015, Peters et al. 2015)

- Risk of hypoglycaemic events possibly leading to seizure, loss of consciousness and death (Unger \& Parkin 2011) less side effects for T2D. Although many potentially useful drugs have been discovered, only 50\% of patients with type 2 diabetes mellitus achieve adequate glycaemic control with currently available medications (Mitka 2013). This could be due to the inability of these medications to target the root causes of the disease. Therefore, to make a real impact on diabetes and to change the natural history of the disease, there is a need to discover new therapeutics that improve the overall function and survival of tissues and cells involved in T2D pathophysiology.

Moreover, as T2D is a result of alterations in multiple complex pathways, drug discovery focusing on a single biological target is often not effective. Therefore, a novel approach is necessary for the identification of new antidiabetic drugs that does not focus on a single specific target, but instead integrates the overall complexity of the disease.

\section{Gene expression signature (GES): a powerful tool in the diagnosis and treatment of complex diseases}

A GES is a small set of genes that have predictive power to differentiate the overall transcriptome in a cell or tissue in response to an external stimulus, without integrating the direct involvement of individual genes (Alizadeh et al. 2000, Konstantopoulos et al. 2011, Chibon 2013). In essence, it can be thought of as a genetic fingerprint of the overall state of the cell. The GES approach has been used extensively as a powerful tool in the diagnosis and treatment of complex diseases such as cancer. In general, to obtain a GES from a normal vs diseased state, the first step is to profile the global gene expression changes in both states using a high-throughput screening technique that measures the expression of a large number of genes simultaneously, such as next-generation sequencing. http://joe.endocrinology-journals.org DOI: $10.1530 / \mathrm{JOE}-16-0515$ (c) 2017 Society for Endocrinology Printed in Great Britain
Published by Bioscientifica Ltd 
Using multiple statistical methods, a minimal set of genes (typically $<100$ ) that are differentially expressed and are able to most accurately discriminate between normal vs diseased state is identified as the GES (Chang et al. 2011). This GES can then be measured in samples of interest using techniques such as next-generation sequencing, multiplex or standard real-time PCR. How this GES is used varies depending on the application as discussed below.

\section{Use of GESs in complex diseases}

Cancer, like many diseases, is a complex multifactorial cellular disease with high heterogeneity in gene expression and phenotype (Rabbani et al. 2014). The large number of genes associated with the growth and proliferation of cancerous cells makes the task of providing optimal treatment extremely difficult. Extensive variability exists in the survival and treatment of patients, and given the fact that most cancer treatments are cytotoxic in nature, choosing drugs for patients must be specific as some of the drugs are more toxic than others and the efficacy can vary among different patient subtypes. Therefore, for therapeutic purposes, it is important to understand how the individual patient's disease state is different from the normal physiological state and what the outcome is likely to be if they receive a specific drug treatment (Kalia 2013).

A classic example for the success of the GES technique is the 70-gene prognosis signature developed by Veer and coworkers, which is currently on the European market and has the potential to predict patient survival and treatment outcomes for breast cancer (van 't Veer et al. 2002). Several other studies also identified GESs for the treatment and diagnosis of cancer such as the 31-gene GES in colorectal cancer that showed predictive power to identify patients with high risk of recurrence (Wang et al. 2015b), the 44-gene GES from 112 oestrogen receptor-positive primary breast carcinomas that exhibited a high predictive power to predict the treatment outcome of patients with progressive disease to tamoxifen (Jansen et al. 2005) and the 41-gene GES derived from breast cancer stem cells that predicted the risk of metastasis and survival in breast cancer patients (Yin et al. 2014). Thus, studies have explored the GES method to identify and confirm gene sets to predict the response to treatment and to classify different tumours to predict responsiveness to different drugs (Sørlie et al. 2001, Ayers et al. 2004, Folgueira et al. 2005, Tabchy et al. 2010).
The use of GES has not been limited to cancer but has been used recently for infectious diseases such as tuberculosis (TB), malaria, influenza and acquired immune deficiency syndrome (AIDS). In particular, the study of TB can be complex as in most people infected with $\mathrm{TB}$, the bacterium remains latent for a time with a high chance of developing disease later in life. Therefore, differentiating latent vs active infection states is important. Further, the immune response to $\mathrm{TB}$ is not well characterised making it difficult to develop new treatments, vaccines or even accurate diagnoses (Berry et al. 2010). Therefore, the prospect of a GES provided a promising path to provide more personalised treatment and diagnosis. Different studies applied GESs that differentiated healthy and diseased states as well as different stages of infection, such as the identification of the 393 transcript signature for active TB that is differentially expressed in whole blood of patients with active and latent TB vs healthy controls (Berry et al. 2010). Additionally, an 86-gene GES discriminates active TB from other inflammatory and infectious diseases (Berry et al. 2010). Moreover, another group has identified a GES that successfully differentiates TB patients, TB-infected healthy individuals and noninfected healthy individuals (Jacobsen et al. 2007). Thus, the GES technique may have an impact for vaccine and therapeutic development leading to a new era of protection in diseases such as TB.

The application of GES technology is not limited to the previously mentioned disease examples but is also valuable to study the adaptive immune response to vaccines to predict vaccine efficacy. One such promising work is the identification and use of a GES to predict immune responses to yellow fever vaccine YF-17D. The distinct GES predicted the magnitude of neutralising antibody response with up to $100 \%$ accuracy (Querec et al. 2009). This approach is now extensively used to study the innate and adaptive immune response to vaccination against various infections such as influenza, HIV and malaria. Categorising the immune response to infections is usually difficult but is crucial for treatment purposes. This could enable more efficient diagnostics as well as a better understanding of the pathogenesis of infection. An 'acute respiratory viral GES' was successfully identified, which was confirmed to have the ability to differentiate between healthy uninfected controls vs acute respiratory infected patients as well as viral vs bacterial infection (Zaas et al. 2009). It is now clear that GES-based techniques have potential to improve diagnosis and treatment outcomes for a range of complex diseases.

Published by Bioscientifica Ltd 


\section{GES for drug discovery}

Conventionally, drug discovery for complex diseases was carried out by screening small molecule libraries that bind or affect a specific target. However, in some cases, the mechanisms underlying the cause of these diseases are highly complex and usually involve the interaction of multiple signalling pathways (Evans \& Guy 2004). Hence, compounds identified through conventional drug discovery methods frequently fail to modulate the underlying cause(s) of complex diseases. Unlike the traditional method, the high-throughput GES-based screening technique does not require prior knowledge of the target, instead this method will identify compounds based on their effect on the overall cellular state represented by the GES. This method has the potential to be a more powerful approach for drug screening for complex diseases such as diabetes.

The GES method uses a defined set of conditions, usually in a cellular model, to create at least two states of interest from which the transcriptome is measured and modelled to generate the GES. This same model can then be treated with a drug library and then the expression level of the GES genes measured using a technique such as qPCR to identify drugs that have a positive influence on the GES genes and are therefore likely having the desired effect in the cell model. By measuring a single and simple readout of qPCR rather than having to carry out more involved and numerous cell characterisation assays, this streamlines the drug discovery process. In addition, the readout measurement of qPCR can be easily performed in a 96- or 384-well format making it more high throughput.

As the GES method is an unbiased and highthroughput approach, many different drug libraries can be screened for efficacy. In fact, by screening available libraries of off-patent, FDA-approved drugs, the timeline from drug discovery to clinical use can be significantly truncated. This approach has been used previously to fast-track an insulin-sensitising drug from GES generation to a successful Phase 2 clinical trial in just three years (Konstantopoulos et al. 2011, Simpson et al. 2014) (discussed in detail in the following section).

Efficacy of the GES method for drug discovery was confirmed by Stegmaier and coworkers using primary acute myelogenous leukaemia (AML) cells (Stegmaier et al. 2004). Using these cells, they generated a GES that differentiated the gene expression pattern of untreated primary AML cells vs differentiated myeloid counterparts (neutrophils and monocytes). The GES was then used to identify candidate compounds that can induce differentiation of AML cells and successfully identify compounds that regulated the GES genes and caused a transition pattern that was similar to actual differentiation (Stegmaier et al. 2004).

In another study, Antipova and coworkers demonstrated the possibility of using a GES in drug discovery where they examined platelet-derived growth factor receptor (PDGFR) signalling, in particular, the extracellular regulated kinase (ERK) pathway, which is often upregulated in tumours and is a target for anticancer therapies (Antipova et al. 2008). They developed a GES that represented PDGFR activation and screened a compound library of small molecules to find compounds that would reverse or turn off the signature. Two compounds were identified that reversed the signature including one compound that was an inhibitor of phospholipase A2, a known regulator of ERK signalling, with the second compound being a novel discovery. These studies demonstrate the potential of using GES technology in drug discovery for complex diseases. A limitation however to using GES for drug discovery is that a defined and robust set of experimental conditions, such as treated cell lines, needs to be available from which the GES can be generated. These same defined conditions will then be treated with compounds from a compound library and the GES measured to identify candidate drugs. Therefore, the quality of the GES, and thus, the drugs it can discover, is limited by the model used. This limitation is not a problem for drug discovery of welldefined diseases/conditions for which an appropriate model exists; however, for diseases for which we have little understanding or no appropriate cellular model, the approach of GES for drug discovery will be limited. In addition, development of a GES requires complex statistical computational methods making it essential to have bioinformatic expertise; however, the development of user-friendly modelling packages is making this less of a limitation (Li et al. 2013 \#1243).

\section{GES in T2D drug discovery}

The first and only study to apply the GES approach to drug discovery in T2D was aimed at reducing insulin resistance. Konstantopoulos and coworkers used an adipocyte cell line (3T3-L1) treated with tumour necrosis factor- $\alpha$ (TNF- $\alpha$ ) to induce insulin resistance. They then further treated these cells with the known insulin sensitising agents, aspirin and troglitazone to 're-sensitise' the cells to insulin, which was their 'biological state of interest'. After the successful

Published by Bioscientifica Ltd. 
reversal of the insulin resistance state, transcriptome profiling was performed using microarray and a GES consisting of 5 genes was generated using Bayesian model selection to identify a small subset of genes that best represented the 're-sensitised state'. This GES was able to successfully discriminate between T2D individuals with low vs high insulin sensitivity showing that it can be used to efficiently subtype patients (Konstantopoulos et al. 2011). The GES was then also used to screen a compound library to identify pharmacological agents that demonstrated similar gene expression pattern to that of the insulin 're-sensitised state' (Konstantopoulos et al. 2011). Out of the identified compounds, one, the carbonic anhydrase inhibitor methazolamide (MTZ), was then further investigated. MTZ exhibited glucoselowering effects and enhanced glucose tolerance in animal models of T2D (Konstantopoulos et al. 2012) and successfully improved glycaemic control in T2D patients in a Phase 2 clinical trial (Simpson et al. 2014) indicating that this agent is a promising new agent to improve insulin sensitivity in T2D. Although this drug discovery endeavour was successful, the complex and multi-tissue nature of T2D means that targeting insulin resistance alone will not combat all the problems that occur in this disease. However, the technique of using a GES for drug discovery can be easily applied to other tissues that play a role in T2D pathophysiology to identify further drugs that can be used in combination to treat multiple aspects of this disease.

\section{Conclusion}

With diabetes affecting more than 422 million adults worldwide (NCD-RisC 2016), the need to discover and develop improved therapies is urgent. Traditional antidiabetic drug interventions are usually initially beneficial; however, as the disease progresses, these drugs eventually fail to improve the treatment outcomes. This failure is linked with the incompetence of these drugs to target the root cause of the disease as well as their inability to modulate the multiple complex pathways associated with the disease. Recent advances in genomewide association studies provided considerable hope for greater understanding of the complexity of the disease; however, we are still a long way from understanding the pathophysiology of complex diseases to sufficiently identify appropriate targets. Further, even if we do identify possible targets, modulating on risk pathway is unlikely to have a beneficial overall effect. The GES-based drug discovery approach is an alternative method for drug discovery, where the drugs are selected based on a more complete measurement of how a cell is responding to them (Schadt et al. 2009) and has proved successful in other complex diseases. Therefore, we propose that GESbased drug discovery is likely to be a powerful tool in the field of complex diseases including T2D.

\section{Declaration of interest}

The authors declare that there is no conflict of interest that could be perceived as prejudicing the impartiality of this review.

\section{Funding}

This research did not receive any specific grant from any funding agency in the public, commercial or not-for-profit sector.

\section{Author contribution statement}

S S and K A-M conceived and drafted the manuscript and were responsible for all sections. $\mathrm{T} \mathrm{C}$ and $\mathrm{K} \mathrm{W}$ contributed to writing the manuscript and revised it critically for intellectual content. All authors approved the final version of the paper.

\section{References}

Alizadeh AA, Eisen MB, Davis RE, Ma C, Lossos IS, Rosenwald A, Boldrick JC, Sabet H, Tran T, Yu X, et al. 2000 Distinct types of diffuse large B-cell lymphoma identified by gene expression profiling. Nature $\mathbf{4 0 3}$ 503-511. (doi:10.1038/35000501)

Andersen MK, Pedersen CE, Moltke I, Hansen T, Albrechtsen A \& Grarup N 2016 Genetics of Type 2 Diabetes: the Power of Isolated Populations. Current Diabetes Reports 16 65. (doi:10.1007/s11892-0160757-z)

Antipova AA, Stockwell BR \& Golub TR 2008 Gene expression-based screening for inhibitors of PDGFR signaling. Genome Biology 9 R47-R47. (doi:10.1186/gb-2008-9-3-r47)

Ashcroft FM \& Rorsman P 2012 Diabetes mellitus and the $\beta$ cell: the last ten years. Cell 148 1160-1171. (doi:10.1016/j.cell.2012.02.010)

American Diabetes Association 2016 Obesity management for the treatment of type 2 diabetes. Sec. 6. In Standards of Medical Care in Diabetes-2016. Diabetes Care 39 S47-S51. (doi:10.2337/dc16-S009)

Aston-Mourney K, Proietto J, Morahan G \& Andrikopoulos S 2008 Too much of a good thing: why it is bad to stimulate the beta cell to secrete insulin. Diabetologia 51 540-545. (doi:10.1007/s00125-0080930-2)

Ayers M, Symmans WF, Stec J, Damokosh AI, Clark E, Hess K, Lecocke M, Metivier J, Booser D, Ibrahim N, et al. 2004 Gene expression profiles predict complete pathologic response to neoadjuvant paclitaxel and fluorouracil, doxorubicin, and cyclophosphamide chemotherapy in breast cancer. Journal of Clinical Oncology 22 2284-2293. (doi:10.1200/ JCO.2004.05.166)

Ayoub WA, Kumar AA, Naguib HS \& Taylor HC 2010 Exenatide-induced acute pancreatitis. Endocrine Practice 16 80-83. (doi:10.4158/ EP09104.CRR) http://joe.endocrinology-journals.org DOI: 10.1530/JOE-16-0515
C 2017 Society for Endocrinology Printed in Great Britain
Published by Bioscientifica Ltd 
Bensellam M, Laybutt DR \& Jonas JC 2012 The molecular mechanisms of pancreatic beta-cell glucotoxicity: recent findings and future research directions. Molecular and Cellular Endocrinology 364 1-27. (doi:10.1016/j.mce.2012.08.003)

Berhan A \& Barker A 2013 Sodium glucose co-transport 2 inhibitors in the treatment of type 2 diabetes mellitus: a meta-analysis of randomized double-blind controlled trials. BMC Endocrine Disorders 13 58. (doi:10.1186/1472-6823-13-58)

Berry MPR, Graham CM, McNab FW, Xu Z, Bloch SAA, Oni T, Wilkinson KA, Banchereau R, Skinner J, Wilkinson RJ, et al. 2010 An interferoninducible neutrophil-driven blood transcriptional signature in human tuberculosis. Nature 466 973-977. (doi:10.1038/nature09247)

Biden TJ, Boslem E, Chu KY \& Sue N 2014 Lipotoxic endoplasmic reticulum stress, beta cell failure, and type 2 diabetes mellitus. Trends in Endocrinology and Metabolism 25 389-398. (doi:10.1016/j. tem.2014.02.003)

Bunck MC, Diamant M, Corner A, Eliasson B, Malloy JL, Shaginian RM, Deng W, Kendall DM, Taskinen MR, Smith U, et al. 2009 One-year treatment with exenatide improves beta-cell function, compared with insulin glargine, in metformin-treated type 2 diabetic patients: a randomized, controlled trial. Diabetes Care 32 762-768. (doi:10.2337/ dc08-1797)

Buse JB, Tan MH, Prince MJ \& Erickson PP 2004 The effects of oral anti-hyperglycaemic medications on serum lipid profiles in patients with type 2 diabetes. Diabetes, Obesity and Metabolism 6 133-156. (doi:10.1111/j.1462-8902.2004.00325.x)

Butler AE, Janson J, Bonner-Weir S, Ritzel R, Rizza RA \& Butler PC 2003 Beta-cell deficit and increased beta-cell apoptosis in humans with type 2 diabetes. Diabetes 52 102-110. (doi:10.2337/ diabetes.52.1.102)

Cervera A, Wajcberg E, Sriwijitkamol A, Fernandez M, Zuo P, Triplitt C, Musi N, DeFronzo RA \& Cersosimo E 2008 Mechanism of action of exenatide to reduce postprandial hyperglycemia in type 2 diabetes. American Journal of Physiology: Endocrinology and Metabolism 294 E846-E852. (doi:10.1152/ajpendo.00030.2008)

Chang JT, Gatza ML, Lucas JE, Barry WT, Vaughn P \& Nevins JR 2011 SIGNATURE: a workbench for gene expression signature analysis. BMC Bioinformatics 12 443. (doi:10.1186/1471-2105-12-443)

Chao EC \& Henry RR 2010 SGLT2 inhibition-a novel strategy for diabetes treatment. Nature Reviews Drug Discovery 9 551-559. (doi:10.1038/nrd3180)

Chibon F 2013 Cancer gene expression signatures - the rise and fall? European Journal of Cancer 49 2000-2009. (doi:10.1016/j. ejca.2013.02.021)

Chu CA, Wiernsperger N, Muscato N, Knauf M, Neal DW \& Cherrington AD 2000 The acute effect of metformin on glucose production in the conscious dog is primarily attributable to inhibition of glycogenolysis. Metabolism 49 1619-1626. (doi:10.1053/ meta.2000.18561)

Dabhi AS, Bhatt NR \& Shah MJ 2013 Voglibose: an alpha glucosidase inhibitor. Journal of Clinical and Diagnostic Research 7 3023-3027. (doi:10.7860/JCDR/2013/6373.3838)

DIAbetes Genetics Replication And Meta-analysis (DIAGRAM) Consortium, Asian Genetic Epidemiology Network Type 2 Diabetes (AGEN-T2D) Consortium, South Asian Type 2 Diabetes (SAT2D) Consortium, Mexican American Type 2 Diabetes (MAT2D) Consortium, Type 2 Diabetes Genetic Exploration by Nex-generation sequencing in muylti-Ethnic Samples (T2D-GENES) Consortium, Mahajan A, Go MJ, Zhang W, Below JE, Gaulton KJ, et al. 2014 Genome-wide trans-ancestry meta-analysis provides insight into the genetic architecture of type 2 diabetes susceptibility. Nature Genetics 46 234-244. (doi:10.1038/ng.2897)

Drucker DJ \& Nauck MA 2006 The incretin system: glucagon-like peptide- 1 receptor agonists and dipeptidyl peptidase- 4 inhibitors in type 2 diabetes. Lancet 368 1696-1705. (doi:10.1016/S01406736(06)69705-5)

Dungan KM, Povedano ST, Forst T, González JGG, Atisso C, Sealls W \& Fahrbach JL 2014 Once-weekly dulaglutide versus once-daily liraglutide in metformin-treated patients with type 2 diabetes (AWARD-6): a randomised, open-label, phase 3, non-inferiority trial. Lancet 384 1349-1357. (doi:10.1016/S0140-6736(14)60976-4)

Elashoff M, Matveyenko AV, Gier B, Elashoff R \& Butler PC 2011 Pancreatitis, pancreatic, and thyroid cancer with glucagonlike peptide-1-based therapies. Gastroenterology 141 150-156. (doi:10.1053/j.gastro.2011.02.018)

Erondu N, Desai M, Ways K \& Meininger G 2015 Diabetic ketoacidosis and related events in the canagliflozin type 2 diabetes clinical program. Diabetes Care 38 1680-1686. (doi:10.2337/dc15-1251)

Esguerra J, Mollet I, Salunkhe V, Wendt A \& Eliasson L 2014 Regulation of pancreatic beta cell stimulus-secretion coupling by microRNAs. Genes 5 1018-1031. (doi:10.3390/genes5041018)

Evans WE \& Guy RK 2004 Gene expression as a drug discovery tool. Nature Genetics 36 214-215. (doi:10.1038/ng0304-214)

Ferrannini E, Muscelli E, Frascerra S, Baldi S, Mari A, Heise T, Broedl UC \& Woerle HJ 2014 Metabolic response to sodium-glucose cotransporter 2 inhibition in type 2 diabetic patients. Journal of Clinical Investigation 124 499-508. (doi:10.1172/JCI72227)

Fineman MS, Shen LZ, Taylor K, Kim DD \& Baron AD 2004 Effectiveness of progressive dose-escalation of exenatide (exendin-4) in reducing dose-limiting side effects in subjects with type 2 diabetes. Diabetes/ Metabolism Research and Reviews 20 411-417. (doi:10.1002/dmrr.499)

Florez H, Luo J, Castillo-Florez S, Mitsi G, Hanna J, Tamariz L, Palacio A, Nagendran S \& Hagan M 2010 Impact of metformin-induced gastrointestinal symptoms on quality of life and adherence in patients with type 2 diabetes. Postgraduate Medicine 122 112-120. (doi:10.3810/pgm.2010.03.2128)

Folgueira MA, Carraro DM, Brentani H, Patrao DF, Barbosa EM, Netto MM, Caldeira JR, Katayama ML, Soares FA, Oliveira CT, et al. 2005 Gene expression profile associated with response to doxorubicinbased therapy in breast cancer. Clinical Cancer Research 11 7434-7443. (doi:10.1158/1078-0432.CCR-04-0548)

Fu AZ, Qiu Y, Davies MJ \& Engel SS 2012 Initial sulfonylurea use and subsequent insulin therapy in older subjects with type 2 diabetes mellitus. Diabetes Therapy 3 12. (doi:10.1007/s13300-012-0012-9)

Geerling JJ, Boon MR, van der Zon GC, van den Berg SA, van den Hoek AM, Lombes M, Princen HM, Havekes LM, Rensen PC \& Guigas B 2014 Metformin lowers plasma triglycerides by promoting VLDLtriglyceride clearance by brown adipose tissue in mice. Diabetes 63 880-891. (doi:10.2337/db13-0194)

Gegick CG \& Altheimer MD 2004 Thiazolidinediones: comparison of long-term effects on glycemic control and cardiovascular risk factors. Current Medical Research and Opinion 20 919-930. (doi:10.1185/03007 9904125003908)

Gier B, Matveyenko AV, Kirakossian D, Dawson D, Dry SM \& Butler PC 2012 Chronic GLP-1 receptor activation by exendin-4 induces expansion of pancreatic duct glands in rats and accelerates formation of dysplastic lesions and chronic pancreatitis in the Kras(G12D) mouse model. Diabetes 61 1250-1262. (doi:10.2337/db11-1109)

Grarup N, Rose CS, Andersson EA, Andersen G, Nielsen AL, Albrechtsen A, Clausen JO, Rasmussen SS, Jorgensen T, Sandbaek A, et al. 2007 Studies of association of variants near the HHEX, CDKN2A/B, and IGF2BP2 genes with type 2 diabetes and impaired insulin release in 10,705 Danish subjects: validation and extension of genome-wide association studies. Diabetes 56 3105-3111. (doi:10.2337/db07-0856)

Guariguata L, Whiting DR, Hambleton I, Beagley J, Linnenkamp U \& Shaw JE 2014 Global estimates of diabetes prevalence for 2013 and projections for 2035. Diabetes Research and Clinical Practice 103 137-149. (doi:10.1016/j.diabres.2013.11.002) http://joe.endocrinology-journals.org

DOI: 10.1530/JOE-16-0515
๑ 2017 Society for Endocrinology Printed in Great Britain
Published by Bioscientifica Ltd. 
Heller C, Kuhn MC, Mulders-Opgenoorth B, Schott M, Willenberg HS, Scherbaum WA \& Schinner S 2011 Exendin-4 upregulates the expression of Wnt-4, a novel regulator of pancreatic beta-cell proliferation. American Journal of Physiology: Endocrinology and Metabolism 301 E864-E872. (doi:10.1152/ajpendo.00144.2011)

Hemmingsen B, Schroll JB, Wetterslev J, Gluud C, Vaag A, Sonne DP, Lundstrøm LH \& Almdal T 2014 Sulfonylurea versus metformin monotherapy in patients with type 2 diabetes: a Cochrane systematic review and meta-analysis of randomized clinical trials and trial sequential analysis. CMAJ Open 2 E162-E175. (doi:10.9778/ cmajo.20130073)

Hull RL, Westermark GT, Westermark P \& Kahn SE 2004 Islet amyloid: a critical entity in the pathogenesis of type 2 diabetes. Journal of Clinical Endocrinology and Metabolism 89 3629-3643. (doi:10.1210/jc.20040405)

Inzucchi SE, Maggs DG, Spollett GR, Page SL, Rife FS, Walton V \& Shulman GI 1998 Efficacy and metabolic effects of metformin and troglitazone in type II diabetes mellitus. New England Journal of Medicine 338 867-872. (doi:10.1056/NEJM199803263381303)

Jacobsen M, Repsilber D, Gutschmidt A, Neher A, Feldmann K, Mollenkopf H, Ziegler A \& Kaufmann SE 2007 Candidate biomarkers for discrimination between infection and disease caused by Mycobacterium tuberculosis. Journal of Molecular Medicine $\mathbf{8 5}$ 613-621. (doi:10.1007/s00109-007-0157-6)

Jansen MPHM, Foekens JA, van Staveren IL, Dirkzwager-Kiel MM, Ritstier K, Look MP, Meijer-van Gelder ME, Sieuwerts AM, Portengen H, Dorssers LCJ, et al. 2005 Molecular classification of tamoxifenresistant breast carcinomas by gene expression profiling. Journal of Clinical Oncology 23 732-740. (doi:10.1200/JCO.2005.05.145)

Jetton TL, Lausier J, LaRock K, Trotman WE, Larmie B, Habibovic A, Peshavaria M \& Leahy JL 2005 Mechanisms of compensatory betacell growth in insulin-resistant rats: roles of Akt kinase. Diabetes 54 2294-2304. (doi:10.2337/diabetes.54.8.2294)

Kahn SE, Cooper ME \& Del Prato S 2014 Pathophysiology and treatment of type 2 diabetes: perspectives on the past, present, and future. Lancet 383 1068-1083. (doi:10.1016/S0140-6736(13)62154-6)

Kalia M 2013 Personalized oncology: recent advances and future challenges. Metabolism 62 (Supplement 1) S11-S14. (doi:10.1016/j. metabol.2012.08.016)

Kim YB, Ciaraldi TP, Kong A, Kim D, Chu N, Mohideen P, Mudaliar S, Henry RR \& Kahn BB 2002 Troglitazone but not metformin restores insulin-stimulated phosphoinositide 3-kinase activity and increases p110beta protein levels in skeletal muscle of type 2 diabetic subjects. Diabetes 51 443-448. (doi:10.2337/diabetes.51.2.443)

Knowler WC, Barrett-Connor E, Fowler SE, Hamman RF, Lachin JM, Walker EA \& Nathan DM 2002 Reduction in the incidence of type 2 diabetes with lifestyle intervention or metformin. New England Journal of Medicine 346 393-403. (doi:10.1056/NEJMoa012512)

Konstantopoulos N, Foletta VC, Segal DH, Shields KA, Sanigorski A, Windmill K, Swinton C, Connor T, Wanyonyi S, Dyer TD, et al. 2011 A gene expression signature for insulin resistance. Physiological Genomics 43 110-120. (doi:10.1152/physiolgenomics.00115.2010)

Konstantopoulos N, Molero JC, McGee SL, Spolding B, Connor T, de Vries M, Wanyonyi S, Fahey R, Morrison S, Swinton C, et al. 2012 Methazolamide is a new hepatic insulin sensitizer that lowers blood glucose in vivo. Diabetes 61 2146-2154. (doi:10.2337/db11-0578)

Kwon DY, Kim YS, Ahn IS, Kim da S, Kang S, Hong SM \& Park S 2009 Exendin-4 potentiates insulinotropic action partly via increasing beta-cell proliferation and neogenesis and decreasing apoptosis in association with the attenuation of endoplasmic reticulum stress in islets of diabetic rats. Journal of Pharmacological Sciences 111 361-371. (doi:10.1254/jphs.09178FP)

Lai Y-J, Hu H-Y, Chen H-H \& Chou P 2015 Dipeptidyl peptidase-4 inhibitors and the risk of acute pancreatitis in patients with type 2 diabetes in Taiwan: a population-based cohort study. Medicine 94 e1906. (doi:10.1097/MD.0000000000001906)
Leahy JL 2005 Pathogenesis of type 2 diabetes mellitus. Archives of Medical Research 36 197-209. (doi:10.1016/j.arcmed.2005.01.003)

Lehtovirta M, Kaprio J, Forsblom C, Eriksson J, Tuomilehto J \& Groop L 2000 Insulin sensitivity and insulin secretion in monozygotic and dizygotic twins. Diabetologia 43 285-293. (doi:10.1007/ s001250050046)

Li F, Cao Y, Han L, Cui X, Xie D, Wang S \& Bo X 2013 GeneExpressionSignature: an R package for discovering functional connections using gene expression signatures. Omics 17 116-118. (doi:10.1089/omi.2012.0087)

Luzi L, Barrett EJ, Groop LC, Ferrannini E \& DeFronzo RA 1988 Metabolic effects of low-dose insulin therapy on glucose metabolism in diabetic ketoacidosis. Diabetes 37 1470-1477. (doi:10.2337/diab.37.11.1470)

Maggs DG, Buchanan TA, Burant CF, Cline G, Gumbiner B, Hsueh WA, Inzucchi S, Kelley D, Nolan J, Olefsky JM, et al. 1998 Metabolic effects of troglitazone monotherapy in type 2 diabetes mellitusa randomized, double-blind, placebo-controlled trial. Annals of Internal Medicine 128 176-185. (doi:10.7326/0003-4819-128-3-199802010-00002)

McGee SL \& Hargreaves M 2010 Histone modifications and skeletal muscle metabolic gene expression. Clinical and Experimental Pharmacology and Physiology 37 392-396. (doi:10.1111/j.14401681.2009.05311.x)

Misbin RI 2004 The phantom of lactic acidosis due to metformin in patients with diabetes. Diabetes Care 27 1791-1793. (doi:10.2337/ diacare.27.7.1791)

Mitka M 2013 More patients get good diabetes control, but only a minority meet all goals. JAMA 309 1335-1336. (doi:10.1001/ jama.2013.2414)

Miyazaki Y, Mahankali A, Matsuda M, Glass L, Mahankali S, Ferrannini E, Cusi K, Mandarino LJ \& DeFronzo RA 2001 Improved glycemic control and enhanced insulin sensitivity in type 2 diabetic subjects treated with pioglitazone. Diabetes Care 24 710-719. (doi:10.2337/ diacare.24.4.710)

Miyazaki Y, He H, Mandarino LJ \& DeFronzo RA 2003 Rosiglitazone improves downstream insulin receptor signaling in type 2 diabetic patients. Diabetes 52 1943-1950. (doi:10.2337/diabetes.52.8.1943)

Motala AA, Omar MA \& Gouws E 1993 High risk of progression to NIDDM in South-African Indians with impaired glucose tolerance. Diabetes 42 556-563. (doi:10.2337/diab.42.4.556)

Nachnani JS, Bulchandani DG, Nookala A, Herndon B, Molteni A, Pandya P, Taylor R, Quinn T, Weide L \& Alba LM 2010 Biochemical and histological effects of exendin-4 (exenatide) on the rat pancreas. Diabetologia 53 153-159. (doi:10.1007/s00125-009-1515-4)

NCD-RisC 2016 Worldwide trends in diabetes since 1980: a pooled analysis of 751 population-based studies with 4.4 million participants. Lancet 387 1513-1530. (doi:10.1016/S01406736(16)00618-8)

Nolan CJ, Leahy JL, Delghingaro-Augusto V, Moibi J, Soni K, Peyot ML, Fortier M, Guay C, Lamontagne J, Barbeau A, et al. 2006 Beta cell compensation for insulin resistance in Zucker fatty rats: increased lipolysis and fatty acid signalling. Diabetologia 49 2120-2130. (doi:10.1007/s00125-006-0305-5)

Peters AL, Buschur EO, Buse JB, Cohan P, Diner JC \& Hirsch IB 2015 Euglycemic diabetic ketoacidosis: a potential complication of treatment with sodium-glucose cotransporter 2 inhibition. Diabetes Care 38 1687-1693. (doi:10.2337/dc15-0843)

Proks P, Reimann F, Green N, Gribble F \& Ashcroft F 2002 Sulfonylurea stimulation of insulin secretion. Diabetes $\mathbf{5 1}$ (Supplement 3) S368-S376. (doi:10.2337/diabetes.51.2007.S368)

Querec TD, Akondy RS, Lee EK, Cao W, Nakaya HI, Teuwen D, Pirani A, Gernert K, Deng J, Marzolf B, et al. 2009 Systems biology approach predicts immunogenicity of the yellow fever vaccine in humans. Nature Immunology 10 116-125. (doi:10.1038/ni.1688)

Rabbani B, Tekin M \& Mahdieh N 2014 The promise of whole-exome sequencing in medical genetics. Journal of Human Genetics 59 5-15. (doi:10.1038/jhg.2013.114) 
Royal Australian College of General Practitioners 2016 General Practice Management of Type 2 Diabetes: 2016-18. East Melbourne, Vic, Australia: RACGP. (available at: https://static.diabetesaustralia com.au/s/fileassets/diabetes-australia/5d3298b2-abf3-487e-9d5e0558566fc242.pdf)

Sandhu MS, Weedon MN, Fawcett KA, Wasson J, Debenham SL, Daly A, Lango H, Frayling TM, Neumann RJ, Sherva R, et al. 2007 Common variants in WFS1 confer risk of type 2 diabetes. Nature Genetics 39 951-953. (doi:10.1038/ng2067)

Saxena R, Elbers CC, Guo Y, Peter I, Gaunt TR, Mega JL, Lanktree MB, Tare A, Castillo BA, Li YR, et al. 2012 Large-scale gene-centric meta-analysis across 39 studies identifies type 2 diabetes loci. American Journal of Human Genetics 90 410-425. (doi:10.1016/j. ajhg.2011.12.022)

Schadt EE, Friend SH \& Shaywitz DA 2009 A network view of disease and compound screening. Nature Reviews Drug Discovery 8 286-295. (doi:10.1038/nrd2826)

Scott LJ, Mohlke KL, Bonnycastle LL, Willer CJ, Li Y, Duren WL, Erdos MR, Stringham HM, Chines PS, Jackson AU, et al. 2007 A genomewide association study of type 2 diabetes in Finns detects multiple susceptibility variants. Science 316 1341-1345. (doi:10.1126/ science.1142382)

Shah P, Ardestani A, Dharmadhikari G, Laue S, Schumann DM, KerrConte J, Pattou F, Klein T \& Maedler K 2013 The DPP-4 inhibitor linagliptin restores beta-cell function and survival in human isolated islets through GLP-1 stabilization. Journal of Clinical Endocrinology and Metabolism 98 E1163-E1172. (doi:10.1210/jc.2013-1029)

Simpson RW, Nicholson GC, Proietto J, Sarah A, Sanders KM, Phillips G, Chambers J, MacGinley R, Orford N, Walder K, et al. 2014 Efficacy and safety of oral methazolamide in patients with type 2 diabetes: a 24-week, placebo-controlled, double-blind study. Diabetes Care 37 3121-3123. (doi:10.2337/dc14-1038)

Sladek R, Rocheleau G, Rung J, Dina C, Shen L, Serre D, Boutin P, Vincent D, Belisle A, Hadjadj S, et al. 2007 A genome-wide association study identifies novel risk loci for type 2 diabetes. Nature 445 881-885. (doi:10.1038/nature05616)

Sørlie T, Perou CM, Tibshirani R, Aas T, Geisler S, Johnsen H, Hastie T, Eisen MB, van de Rijn M, Jeffrey SS, et al. 2001 Gene expression patterns of breast carcinomas distinguish tumor subclasses with clinical implications. PNAS 98 10869-10874. (doi:10.1073/ pnas.191367098)

Stegmaier K, Ross KN, Colavito SA, O’Malley S, Stockwell BR \& Golub TR 2004 Gene expression-based high-throughput screening(GE-HTS) and application to leukemia differentiation. Nature Genetics 36 257-263. (doi:10.1038/ng1305)

Steil GM, Trivedi N, Jonas JC, Hasenkamp WM, Sharma A, BonnerWeir S \& Weir GC 2001 Adaptation of beta-cell mass to substrate oversupply: enhanced function with normal gene expression. American Journal of Physiology: Endocrinology and Metabolism 280 E788-E796.

Tabchy A, Valero V, Vidaurre T, Lluch A, Gomez H, Martin M, Qi Y, Barajas-Figueroa LJ, Souchon E, Coutant C, et al. 2010 Evaluation of a 30-gene paclitaxel, fluorouracil, doxorubicin, and cyclophosphamide chemotherapy response predictor in a multicenter randomized trial in breast cancer. Clinical Cancer Research 16 5351-5361. (doi:10.1158/1078-0432.CCR-10-1265)

Tuomilehto J, Lindstrom J, Eriksson JG, Valle TT, Hamalainen H, Ilanne-Parikka P, Keinanen-Kiukaanniemi S, Laakso M, Louheranta A, Rastas M, et al. 2001 Prevention of type 2 diabetes mellitus by changes in lifestyle among subjects with impaired glucose tolerance. New England Journal of Medicine 344 1343-1350. (doi:10.1056/ NEJM200105033441801)

Unger J \& Parkin C 2011 Hypoglycemia in insulin-treated diabetes: a case for increased vigilance. Postgraduate Medicine 123 81-91. (doi:10.3810/pgm.2011.07.2307)

van 't Veer LJ, Dai H, van de Vijver MJ, He YD, Hart AAM, Mao M, Peterse HL, van der Kooy K, Marton MJ, Witteveen AT, et al. 2002 Gene expression profiling predicts clinical outcome of breast cancer. Nature 415 530-536. (doi:10.1038/415530a)

Voight BF, Scott LJ, Steinthorsdottir V, Morris AP, Dina C, Welch RP, Zeggini E, Huth C, Aulchenko YS, Thorleifsson G, et al. 2010 Twelve type 2 diabetes susceptibility loci identified through large-scale association analysis. Nature Genetics 42 579-589. (doi:10.1038/ ng.609)

Wang C, Chen X, Ding X, He Y, Gu C \& Zhou L 2015a Exendin-4 promotes beta cell proliferation via PI3k/Akt signalling pathway. Cellular Physiology and Biochemistry 35 2223-2232. (doi:10.1159/000374027)

Wang L, Shen X, Wang Z, Xiao X, Wei P, Wang Q, Ren F, Wang Y, Liu $\mathrm{Z}$, Sheng W, et al. 2015b A molecular signature for the prediction of recurrence in colorectal cancer. Molecular Cancer 14 22. (doi:10.1186/ s12943-015-0296-2)

Weeks DE \& Lathrop GM 1995 Polygenic disease: methods for mapping complex disease traits. Trends in Genetics 11 513-519. (doi:10.1016/ S0168-9525(00)89163-5)

Weir GC \& Bonner-Weir S 2004 Five stages of evolving beta-cell dysfunction during progression to diabetes. Diabetes $\mathbf{5 3}$ (Supplement 3) S16-S21. (doi:10.2337/diabetes.53.suppl_3.S16)

Yin ZQ, Liu JJ, Xu YC, Yu J, Ding GH, Yang F, Tang L, Liu BH, Ma Y, Xia YW, et al. 2014 A 41-gene signature derived from breast cancer stem cells as a predictor of survival. Journal of Experimental and Clinical Cancer Research 33 49. (doi:10.1186/1756-9966-33-49)

Zaas AK, Chen M, Varkey J, Veldman T, Hero Iii AO, Lucas J, Huang Y, Turner R, Gilbert A, Lambkin-Williams R, et al. 2009 Gene expression signatures diagnose influenza and other symptomatic respiratory viral infections in humans. Cell Host and Microbe 6 207-217. (doi:10.1016/j.chom.2009.07.006)

Zeggini E, Scott LJ, Saxena R, Voight BF, Marchini JL, Hu T, de Bakker PI, Abecasis GR, Almgren P, Andersen G, et al. 2008 Meta-analysis of genome-wide association data and large-scale replication identifies additional susceptibility loci for type 2 diabetes. Nature Genetics $\mathbf{4 0}$ 638-645. (doi:10.1038/ng.120)

Zhou G, Myers R, Li Y, Chen Y, Shen X, Fenyk-Melody J, Wu M, Ventre J, Doebber T, Fujii N, et al. 2001 Role of AMP-activated protein kinase in mechanism of metformin action. Journal of Clinical Investigation $\mathbf{1 0 8}$ 1167-1174. (doi:10.1172/JCI13505)

Received in final form 28 November 2016

Accepted 7 December 2016

Accepted Preprint published online 7 December 2016 http://joe.endocrinology-journals.org

DOI: $10.1530 / \mathrm{JOE}-16-0515$
๑) 2017 Society for Endocrinology Printed in Great Britain 